\title{
Isolation and Characterization of Escherichia coli Mutants Lacking Inducible Cyanase
}

\author{
By MICHEL GUILLOTON* AND FRANCIS KARST \\ Laboratoire de Biochimie et Génétique des Microorganismes, JE CNRS 034620, \\ Université de Poitiers, 40 Avenue du Recteur Pineau, 86022 Poitiers Cédex, France
}

(Received 14 July 1986; revised 17 September 1986)

To determine the physiological role of cyanate aminohydrolase (cyanase, EC 3.5.5.3) in bacteria, mutants of Escherichia coli $\mathrm{K} 12$ devoid of this inducible activity were isolated and their properties investigated. Five independent mutations were localized next to lac; three of them lay beween $l a c Y$ and $\operatorname{cod} A$. Thus cyanase activity could depend on the integrity of one gene or set of clustered genes; we propose for this locus the symbol cnt. Growth of the mutant strains was more sensitive to cyanate than growth of wild-type strains. This difference was noticeable in synthetic medium in the presence of low concentrations of cyanate $(\leqslant 1 \mathrm{~mm})$. Higher concentrations inhibited growth of both wild-type and mutant strains. Urea in aqueous solutions dissociates slowly into ammonium cyanate. Accordingly wild-type strains were able to grow on a synthetic medium containing $0.5 \mathrm{M}$-urea whereas mutants lacking cyanase were not. We conclude that cyanase could play a role in destroying exogenous cyanate originating from the dissociation of carbamoyl compounds such as urea; alternatively cyanate might constitute a convenient nitrogen source for bacteria able to synthesize cyanase in an inducible way.

\section{INTRODUCTION}

Cyanate aminohydrolase (EC 3.5.5.3), also termed cyanase, is an inducible enzyme in bacteria, which hydrolyses cyanate into ammonium and hydrogenocarbonate:

$$
\mathrm{NCO}^{-}+\mathrm{H}^{+}+2 \mathrm{H}_{2} \mathrm{O} \rightleftharpoons \mathrm{NH}_{4}^{+}+\mathrm{HCO}_{3}^{-}
$$

This enzyme has been found in Escherichia coli B (Taussig, 1960) and in a Flavobacterium sp. (Guilloton \& Hargreaves, 1972). Purification and kinetic studies of the enzyme from E. coli B have been achieved (Anderson, 1980). It has been demonstrated that carbon dioxide is an essential activator for the enzymes from both Flavobacterium sp. and $E$. coli (Guilloton \& Hargreaves, 1972; Anderson, 1980). The covalent structure of the enzyme has been determined (Chin et al., 1983).

The presence of this enzyme in bacteria raises the question of its physiological role, and also of the availability of its substrate, cyanate. Cyanate is not, to our knowledge, the product of any metabolic reaction; this molecule may be considered as a by-product of the metabolism of carbamoyl compounds, chiefly carbamoylphosphate and urea. Anderson (1980) proposed that cyanase might hydrolyse endogenous cyanate arising from the dissociation of carbamoylphosphate. On the other hand, urea dissociates slowly into ammonium cyanate (Marier \& Rose, 1964); urea present in some biological fluids could constitute an exogenous source of cyanate. The experiments reported here were done in order to determine the possible roles of cyanase in bacteria.

\section{METHODS}

Bacterial stains and transducing phage. All strains were derivatives of Escherichia coli K12. They are listed in Table 1. The transducing phage used was Pl vir, kindly supplied by Dr Maxime Schwartz, (Institut Pasteur, Paris, 
Table 1. E. coli strains

\begin{tabular}{|c|c|c|}
\hline Strain & Genotype & Source or referenc \\
\hline $\mathbf{H}$ & $\operatorname{Hfr}\left(\lambda^{+}\right)$ & M. Schwartz \\
\hline R5 & Hfr lac Y mal mtl thi $\left(\lambda^{+}\right)$ & J. H. Miller \\
\hline pop 1375 & $\mathrm{~F}^{-} \operatorname{trp} A$ his supF recA srl:: $\operatorname{Tn} 10$ & M. Schwartz \\
\hline C600F'lac & $\mathrm{F}^{-}$cnt lac $/ F^{\prime}$ cnt $^{+} \mathrm{lac}^{+}$ & - F Jacoh \\
\hline $\mathrm{C} 600$ & $\mathrm{~F}^{-}$leu cht lacY trp his $\left(\lambda^{+}\right)$ & F. Jacoo \\
\hline ED 8689 & $\mathrm{~F}^{-}$cnt lac gal $\left(\lambda^{-}\right)$ & G. G. Wilson \\
\hline PC 0698 & $\mathrm{~F}^{-}$purA thr leu proA pyr codA lacY gal xyl mil mal lam tsx phx rpsL & P. G. de Haan \\
\hline MC 4100 & $\mathrm{~F}^{-}[$ara $\mathrm{D139}] \Delta(\operatorname{argF}-\mathrm{lac}) 169 \mathrm{fb}-5301 \mathrm{pts} F 25 \mathrm{relAl} \mathrm{rpsL1} 150$ deoCl $\left(\lambda^{-}\right)$ & Rachmann \\
\hline X7026 & $\mathrm{F}^{-} \Delta(\mathrm{gpt}-\mathrm{lac}) 5$ supE44 relA1 spoTl thi-1 $\left(\lambda^{-}\right)$ & imann \\
\hline JA 200 & $\mathrm{~F}^{+}$thr leu lacY $\mathrm{rec} A$ trpE5 & A. Piérard \\
\hline BGM 017 & $\mathrm{~F}^{-}$gal proC rpsL & \\
\hline BGM 022 & as $\mathrm{R} 5$ but $\mathrm{cnt} 2$ & \\
\hline BGM 023 & as $\mathrm{R} 5$ but cnt 3 & \\
\hline BGM 024 & as $\mathrm{R} 5$ but cnt 4 & \\
\hline BGM 025 & as $\mathrm{R} 5$ but $c n t 5$ & \\
\hline BGM 035 & as $\mathrm{Hfr} \mathrm{H}$ but cnt 15 & This work \\
\hline BGM 132 & as PC 0698 but $\mathrm{gal}^{+}$ & \\
\hline BGM 133 & 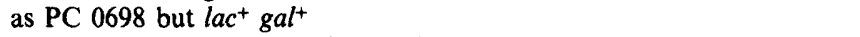 & \\
\hline BGM 137 & as PC 0698 but $\operatorname{cod}^{+}$cnt2 lacY $\mathrm{gal}^{+}$ & \\
\hline BGM 160 & $\mathrm{~F}^{-}$cnt lac srl:: $\mathrm{Tn} 10$ rec $A$ & \\
\hline BGM 182 & as PC 0698 but gyrA & \\
\hline
\end{tabular}

France). Strain BGM 017 is a $\mathrm{Cnt}^{+} \mathrm{Lac}^{+}$transductant of a proC $r p s L$ derivative of strain ED 8689. Strain BGM 132 is a Gal ${ }^{+}$transductant of strain PC 0698. BGM 133 is a Lac' revertant of BGM 132. BGM 137 was obtained by infecting BGM 133 with phage $\mathrm{Pl}$ grown on BGM 022 and selecting for the $\mathrm{Cod}^{+}$character; resulting transductants were scored for $\mathrm{Lac}^{-} \mathrm{Cnt}^{-}$. In order to obtain strain BGM $160(\mathrm{recA})$, strain $\mathrm{C}^{2} \mathrm{O} \mathrm{F}^{\prime} l a c^{+}$was cured of the episome; the resulting $\mathrm{F}^{-}$cnt lac strain was transduced to tetracycline resistance using a phage $\mathrm{P} 1$ grown on strain pop 1375 (recA srl::Tn10). This strain was scored as a $\mathrm{Rec}^{-}$strain among the resulting $\mathrm{Tet}^{\mathrm{R}} \mathrm{Srl}^{-}$ transductants. Strain BGM 182 was obtained by plating PC 0698 on L broth supplemented with nalidixic acid $\left(40 \mu \mathrm{g} \mathrm{ml}^{-1}\right)$ (Hane \& Wood, 1969).

Genetic techniques. Conjugation and P1 mediated transduction were done as described by Miller (1972).

Culture media. L broth and synthetic medium (minimal A medium) were prepared as described by Miller (1972). Glucose was added to this synthetic medium at a concentration of $0.4 \%$. Indicator plates used in the detection of the $\mathrm{Cnt}^{+}$phenotype were composed of Difco Nutrient Broth (0.8\%) supplemented with Difco Bacto agar ( $2 \%$, w/v, Batch no. 418470$)$ and $\mathrm{NaCl}(0.5 \%)$; recrystallized $\mathrm{KNCO}$ was added to a final concentration of $10 \mathrm{~mm}$, after sterilization and cooling to $60^{\circ} \mathrm{C}$.

Growth conditions. Bacteria were cultivated at $37^{\circ} \mathrm{C}$ with shaking in $25 \times 250 \mathrm{~mm}$ test tubes; the optical density (OD) of the tubes was measured at $575 \mathrm{~nm}$ with a Coleman Junior AII spectrophotometer. OD $_{575}$ was proportional to cell density up to $0 \cdot 6$. To study the effects of cyanate on the physiology of bacteria, overnight cultures in standard synthetic medium were diluted into the same medium to an $\mathrm{OD}_{575}$ of approximately 0.05 . Potassium cyanate was added when the $\mathrm{OD}_{575}$ reached 0.2 and growth was monitored for a further $150 \mathrm{~min}$.

Assay of cyanate. Spectrophotometric determination of cyanate was done according to Guilloton \& Karst (1985).

Assay of cyanase. Cell-free extracts or toluene-treated cells were incubated at $37^{\circ} \mathrm{C}$ in the presence of $20 \mathrm{mM}$ veronal buffer, $5 \mathrm{mM}-\mathrm{KNCO}$ and $5 \mathrm{mM}-\mathrm{KHCO}_{3}, \mathrm{pH} 8$. Ammonium produced by the enzymic hydrolysis of KNCO was estimated by using the Berthelot reaction (Lubochinsky \& Zalta, 1955). One unit of cyanase is defined as the amount of enzyme which catalyses the production of $1 \mu \mathrm{mol} \mathrm{NH}_{4}^{+} \mathrm{min}^{-1}$ under these conditions.

Test for the presence of cyanase in toluene-treated cells. Cells to be tested for the presence of cyanase were treated with toluene at $37^{\circ} \mathrm{C}$ for $30 \mathrm{~min}$ and mixed with $1 \mathrm{ml}$ of a medium containing $5 \mathrm{mM}$-veronal, $5 \mathrm{mM}-\mathrm{K} \mathrm{NCO}, 1 \mathrm{mM}$ $\mathrm{KHCO}_{3}$ and $0.1 \%$ bromothymol blue, $\mathrm{pH}$ 7. Cyanate hydrolysis resulted in an increase of the $\mathrm{pH}$ and the colour turned deep blue.

\section{RESULTS AND DISCUSSION}

\section{Identification of strains with inducible cyanase activity}

Description of the $\mathrm{Cnt}^{+}$phenotype. Cyanase activity could be induced in wild-type $E$. coli cells growing exponentially in $\mathrm{L}$ broth when cyanate was present at concentrations ranging from 1 to $10 \mathrm{~mm}$. Specific activities of cyanase ranging from 0.25 to 0.5 units (mg protein) ${ }^{-1}$ were 


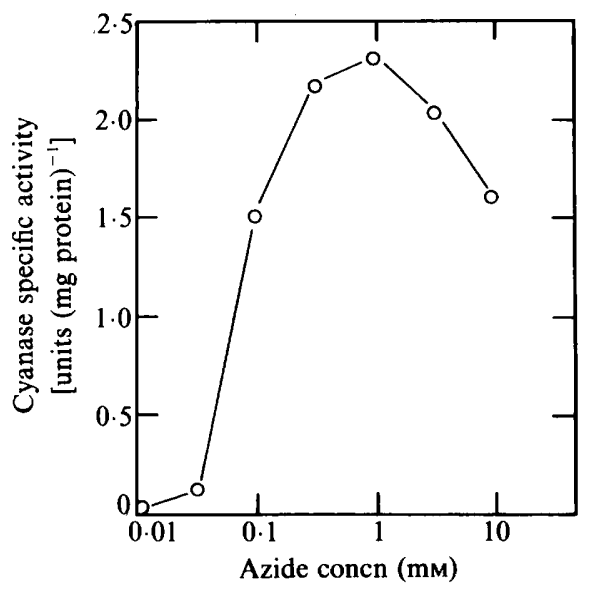

Fig. 1. Induction of cyanase by azide. $E$. coli $\mathrm{Hfr} \mathrm{H}$ was grown at $37^{\circ} \mathrm{C}$ in standard synthetic medium. Sodium azide was added to exponentially growing cultures when the $\mathrm{OD}_{575}$ reached $0 \cdot 2$. After a further incubation of $60 \mathrm{~min}$, growth was stopped by addition of chloramphenicol $\left(40 \mu \mathrm{g} \mathrm{ml}^{-1}\right)$, and the cells were harvested by centrifugation and washed with buffered saline. Cyanase activity was measured in toluene-treated cells (see Methods).

obtained. Higher concentrations of cyanate were toxic and led to growth inhibition and low enzyme levels.

Such induction was also observed in wild-type cells cultivated on solid nutrient media. Colonies of wild-type cells growing on cyanase indicator plates (see Methods) showed a white precipitate in their centre (constituting the $\mathrm{Cnt}^{+}$phenotype) while colonies of cyanase-lacking strains remained translucent. This colony appearance of wild-type cells was strongly dependent upon the presence of both phosphate and calcium ions in the medium. Thus the $\mathrm{Cnt}^{+}$phenotype was believed to result from the precipitation of a calcium phosphate salt. The formation of this insoluble salt is probably driven by the alkalinization of the medium following cyanate hydrolysis. This precipitate also formed in replica-plated colonies and in spot tests of wild-type cells grown on the same indicator medium. This identification of the $\mathrm{Cnt}^{+}$phenotype was particularly useful in screening the clones obtained after conjugation or transduction experiments.

Induction of cyanase by azide. Azide $(\mathrm{N}=\mathrm{N}=\mathrm{N})^{-}$, which is isosteric and isoelectronic to cyanate $(\mathrm{N}=\mathrm{C}=\mathrm{O})^{-}$(Wagner, 1965), induces cyanase in a Flavobacterium sp. (Guilloton \& Hargreaves, 1972). It also induced this activity in $E$. coli, a maximum specific activity of 2.3 units (mg protein $)^{-1}$ being obtained with strain $\mathrm{Hfr} \mathrm{H}$ grown in standard synthetic medium in the presence of $1 \mathrm{~mm}-\mathrm{NaN}_{3}$ (Fig. 1). Since this concentration (and higher ones) substantially inhibited cell growth, induction of cyanase was routinely obtained with an azide concentration of $0.3 \mathrm{~mm}$ both in liquid and solid media. Cyanase could be detected by the cyanase test on toluene-treated cells (see Methods).

Routinely, all the clones obtained after conjugation or transduction experiments were grown on the cyanase indicator plates and on $\mathrm{L}$ broth/azide plates. All the strains exhibiting the $\mathrm{Cnt}^{+}$ phenotype were shown to possess a cyanase activity inducible by either cyanate or azide. Conversely none of the $\mathrm{Cnt}^{-}$strains synthesized cyanase in the presence of either cyanate or azide.

\section{Genetic characterization of cnt mutants}

Mutagenesis and selection of mutants. Wild-type cells $\left(\mathrm{Cnt}^{+}\right.$phenotype) were plated on solid $\mathrm{L}$ broth medium and mutagenized by UV until $1 \%$ survival was obtained. After an incubation of $24 \mathrm{~h}$, the cells were scraped, suspended in buffered saline and plated on cyanase indicator medium in order to obtain 300 colonies per plate. Translucent colonies were subcloned on the 
Table 2. Analysis of recombinants obtained from conjugation between $\mathrm{Hfr} H$ and $\mathrm{C} 600 \mathrm{~F}^{-}$ (leu cnt lac trp his)

\begin{tabular}{lcccccc}
\multirow{2}{*}{$\begin{array}{c}\text { Selected } \\
\text { phenotype }\end{array}$} & $\begin{array}{c}\text { No. of } \\
\text { recombinants }\end{array}$ & $\overbrace{\mathrm{Leu}^{+}}$ & $\mathrm{Lac}^{+}$ & $\mathrm{Cnt}^{+}$ & $\mathrm{Trp}^{+}$ & $\mathrm{Lac}^{+} \mathrm{Cnt}^{+}$ \\
$\mathrm{Leu}^{+}$ & 88 & - & 16 & 16 & 0 & 16 \\
& 88 & - & $(18 \%)$ & $(18 \%)$ & $(0 \%)$ & $(18 \%)$ \\
$\mathrm{Lac}^{+}$ & 98 & 73 & - & 98 & 0 & 98 \\
& & $(74 \%)$ & - & $(100 \%)$ & $(0 \%)$ & $(100 \%)$ \\
$\mathrm{Cnt}^{+}$ & 88 & 64 & 88 & - & 1 & 88 \\
& & $(73 \%)$ & $(100 \%)$ & - & $(1 \%)$ & $(100 \%)$ \\
$\mathrm{Trp}^{+}$ & 81 & 16 & 7 & 7 & - & 7 \\
& & $(20 \%)$ & $(9 \%)$ & $(9 \%)$ & - & $(9 \%)$
\end{tabular}

Table 3. Cotransduction of lac with cnt

\begin{tabular}{|c|c|c|c|c|c|}
\hline \multirow{2}{*}{$\begin{array}{c}\text { Donor } \\
\text { strain } \\
\text { (relevant } \\
\text { genotype) }\end{array}$} & \multirow{2}{*}{$\begin{array}{l}\text { Recipient } \\
\text { strain } \\
\text { (relevant } \\
\text { genotype) }\end{array}$} & \multirow{2}{*}{$\begin{array}{l}\text { Selected } \\
\text { phenotype } \\
\text { (no.) }\end{array}$} & \multicolumn{2}{|c|}{ Unselected phenotype } & \multirow[b]{2}{*}{$\begin{array}{c}\text { Linkage } \\
(\%)\end{array}$} \\
\hline & & & $\mathrm{Cnt}^{+}$ & $\mathrm{Cnt}^{-}$ & \\
\hline $\mathrm{Hfr} \mathbf{H}$ & $\begin{array}{l}\text { ED } 8689 \\
\text { (cnt lac) }\end{array}$ & $\begin{array}{l}\mathrm{Lac}^{+} \\
(665)\end{array}$ & 665 & 0 & 100 \\
\hline Hfr $\mathrm{H}$ & $\begin{array}{l}\text { BGM } 022 \\
(\text { cnt } 2 \text { lac Y })\end{array}$ & $\begin{array}{l}\mathrm{Lac}^{+} \\
(211)\end{array}$ & 184 & 27 & 87 \\
\hline BGM 133 & $\begin{array}{l}\text { BGM } 137 \\
\text { (cnt2 lac Y) }\end{array}$ & $\begin{array}{l}\mathrm{Lac}^{+} \\
(324)\end{array}$ & 284 & 40 & 88 \\
\hline BGM 017 & $\begin{array}{l}\text { BGM } 023 \\
(\text { cnt3 lac } Y)\end{array}$ & $\begin{array}{l}\mathrm{Lac}^{+} \\
(358)\end{array}$ & 358 & 0 & 100 \\
\hline $\mathrm{Hfr} \mathbf{H}$ & $\begin{array}{l}\text { BGM } 024 \\
(\text { cnt4 lac } Y)\end{array}$ & $\begin{array}{l}\mathrm{Lac}^{+} \\
(190)\end{array}$ & 153 & 37 & 80 \\
\hline Hfr $\mathbf{H}$ & $\begin{array}{l}\text { BGM } 025 \\
\text { (cnt5 lac } Y)\end{array}$ & $\begin{array}{l}\mathrm{Lac}^{+} \\
(99)\end{array}$ & 98 & 1 & 99 \\
\hline $\begin{array}{l}\text { BGM } 035 \\
\text { (cnt15) }\end{array}$ & $\begin{array}{l}\text { R5 } \\
(\operatorname{lac} Y)\end{array}$ & $\begin{array}{l}\mathrm{Lac}^{+} \\
(772)\end{array}$ & 174 & 598 & 77 \\
\hline
\end{tabular}

same medium and their phenotype was checked. One $\mathrm{Cnt}^{-}$strain could be isolated for every $2000 \mathrm{Cnt}^{+}$colonies.

Mapping of cnt mutations. We have studied five selected mutants (BGM 022, 023, 024 and 025, derivatives of $\mathrm{Hfr} \mathrm{R} 5$, and BGM 035, a derivative of $\mathrm{Hfr} \mathrm{H}$ ) along with two 'naturally' $\mathrm{Cnt}^{-}$ strains held by our laboratory (ED 8689 and $\mathrm{C}^{2} 00 \mathrm{~F}^{-}$).

An interrupted mating experiment using $\mathrm{Hfr} \mathrm{H}$ and $\mathrm{C}^{2} 00 \mathrm{~F}^{-}$(leu cnt lac trp his) showed that the time of entry was identical for the $\mathrm{Cnt}^{+}$and $\mathrm{Lac}^{+}$characters. Phenotypic analysis of the selected recombinants showed a strong linkage between the $c n t$ and lac markers (Table 2). Thus, the cnt mutation studied lies close to lac at 8 min on the linkage map (Bachmann, 1983).

In order to determine the location of the cnt mutations more precisely, transductional crosses were made between $\mathrm{Cnt}^{+}$and $\mathrm{Cnt}^{-}$strains. Since the cyanase indicator medium cannot be used as a selection medium for the $\mathrm{Cnt}^{+}$clones, mapping experiments were done by transduction of characters linked to $c n t$ and subsequent analysis of the transductants. Transduction experiments using $\mathrm{Lac}^{+}$donor strains and $\mathrm{Lac}^{-}$recipient strains showed that the $\mathrm{Lac}$ and $\mathrm{Cnt}$ characters were closely linked. [Strain $\mathrm{C}^{2} 00 \mathrm{~F}^{-}$(leu cnt lac trp his) could not be transduced for $\mathrm{Lac}^{+}$by $\mathrm{Pl}$ generalized transduction; generalized transduction by T4GT (Wilson et al., 1979) also failed to transduce this strain for the $\mathrm{Lac}^{+}$phenotype.] The frequencies of cotransduction were between 77 and $100 \%$ (Table 3). Localization of three cnt mutations (cnt2, cnt4 and cnt 15) was achieved 
Table 4. Mapping of cnt mutations using three-point analysis

\begin{tabular}{|c|c|c|c|}
\hline $\begin{array}{c}\text { Cross } \\
\text { (relevant phenotype) }\end{array}$ & $\begin{array}{c}\text { Selected } \\
\text { phenotype } \\
\text { (no. of clones tested) }\end{array}$ & $\begin{array}{l}\text { Unselected } \\
\text { phenotypes } \\
\text { (no. of clones) }\end{array}$ & $\begin{array}{l}\text { Frequency } \\
\qquad(\%)\end{array}$ \\
\hline $\begin{array}{l}\phi P 1 \text { [BGM 035] (cnt 15) } \\
\times \\
\text { PC } 0698(\operatorname{cod} A \operatorname{lac} Y)\end{array}$ & $\begin{array}{l}\mathrm{Cod}^{+} \\
(306)\end{array}$ & $\begin{array}{l}\mathrm{Cnt}^{-} \mathrm{Lac}^{+}(218) \\
\mathrm{Cnt}^{-} \mathrm{Lac}^{-}(43) \\
\mathrm{Cnt}^{+} \mathrm{Lac}^{-}(30) \\
\mathrm{Cnt}^{+} \mathrm{Lac}^{+}(15)\end{array}$ & $\begin{array}{r}71 \\
14 \\
10 \\
5\end{array}$ \\
\hline $\begin{array}{l}\phi P 1 \text { [BGM 022] (cnt2 lac } Y) \\
\times \\
\text { BGM } 133(\operatorname{cod} A)\end{array}$ & $\begin{array}{c}\mathrm{Cod}^{+} \\
(92)\end{array}$ & $\begin{array}{lr}\mathrm{Cnt}^{-} \mathrm{Lac}^{+} & (20) \\
\mathrm{Cnt}^{-} \mathrm{Lac}^{-} & (54) \\
\mathrm{Cnt}^{+} \mathrm{Lac}^{-} & (1) \\
\mathrm{Cnt}^{+} \mathrm{Lac}^{+} & (17)\end{array}$ & $\begin{array}{r}22 \\
59 \\
1 \\
18\end{array}$ \\
\hline $\begin{array}{l}\phi \text { P1 [BGM 024] cnt4 lac Y) } \\
\times \\
\text { BGM } 133(\operatorname{cod} A)\end{array}$ & $\begin{array}{c}\mathrm{Cod}^{+} \\
(52)\end{array}$ & $\begin{array}{lr}\mathrm{Cnt}^{-} \mathrm{Lac}^{+} & (22) \\
\mathrm{Cnt}^{-} \mathrm{Lac}^{-} & (22) \\
\mathrm{Cnt}^{+} \mathrm{Lac}^{-} & (0) \\
\mathrm{Cnt}^{+} \mathrm{Lac}^{+} & (8)\end{array}$ & $\begin{array}{r}42 \\
42 \\
0 \\
15\end{array}$ \\
\hline $\begin{array}{l}\phi \mathrm{P} 1[\mathrm{BGM} 133](\operatorname{cod} A) \\
\times \\
\text { BGM } 137(c n t 2 \text { lac } Y)\end{array}$ & $\begin{array}{l}\mathrm{Lac}^{+} \\
(324)\end{array}$ & $\begin{array}{l}\mathrm{Cod}^{-} \mathrm{Cnt}^{+}(220) \\
\mathrm{Cod}^{+} \mathrm{Cnt}^{+} \\
\mathrm{Cod}^{+} \mathrm{Cnt}^{-} \\
\mathrm{Cod}^{-} \mathrm{Cnt}^{-}\end{array}$ & $\begin{array}{r}68 \\
20 \\
12 \\
1\end{array}$ \\
\hline
\end{tabular}

Table 5. Phenotypes of sexductants obtained by crossing $F^{-}$strains with $C 600 F^{\prime} l a c$

\begin{tabular}{|c|c|c|c|}
\hline \multirow{2}{*}{$\begin{array}{l}\text { Strain } \\
\text { [relevant genotype] }\end{array}$} & \multicolumn{3}{|c|}{ Phenotypic trait } \\
\hline & Cod & Cnt & Lac \\
\hline $\begin{array}{l}\text { MC } 4100[\Delta(\arg F-l a c)] \\
\text { MC } 4100[\Delta(a r g F-l a c)] F^{\prime} l a c\end{array}$ & $\begin{array}{l}\text { wt } \\
\text { wt }\end{array}$ & - & - \\
\hline $\begin{array}{l}\text { X } 7026[\Delta(g p t-l a c)] \\
X 7026[\Delta(g p t-l a c)] F^{\prime} l a c\end{array}$ & $\begin{array}{l}\text { wt } \\
\text { wt }\end{array}$ & - & - \\
\hline $\begin{array}{l}\text { C600 [cnt lac }]^{*} \\
\mathrm{C} 600[\text { cnt lac }] \mathrm{F}^{\prime} l a c^{*}\end{array}$ & $\begin{array}{l}\text { wt } \\
\text { wt }\end{array}$ & - & - \\
\hline $\begin{array}{l}\text { BGM } 132[\operatorname{cod} A \text { lac } Y] \\
\text { BGM } 132[\operatorname{cod} A \text { lac } Y] \mathrm{F}^{\prime} l a c\end{array}$ & - & $\begin{array}{l}\text { wt } \\
\text { wt }\end{array}$ & $\overline{+}$ \\
\hline
\end{tabular}

* The strain C600 employed was C600 (leu cnt lac trp his).

by three-point analysis using $\operatorname{cod} A$ strains (de Haan et al., 1972). These experiments are summarized in Table 4. The results of four analyses showed that the three mutations cnt 15, cnt 2 and $c n t 4$ were located between $\operatorname{cod} A$ and lac $Y$ (Table 4). Cotransduction frequencies of $c n t$ with $\operatorname{cod} A$ were between 80 and $88 \%$. Three-point analysis was not done with strains BGM 023 (cnt3), BGM 025 (cnt5) and ED 8689 since the cotransduction frequencies of lac with the cnt mutations were too high.

From these experiments, it appeared that the cnt mutations studied were located at the same locus. The strong linkage between $c n t, \operatorname{cod} A$ and lac was further demonstrated by two independent lines of evidence. Strain $\mathrm{C}^{2} 00 \mathrm{~F}^{\prime} \mathrm{lac}^{+}$is phenotypically $\mathrm{Lac}^{+} \mathrm{Cnt}^{+}$and becomes $\mathrm{Cnt}^{-} \mathrm{Lac}^{-}$when cured of the episome. From the results presented in Table 5 it can be concluded that the $\mathrm{F}^{\prime} l a c$ episome also carries $c n t$ and $\operatorname{cod} A$ wild-type genes since all sexductants obtained from $\mathrm{F}^{-} \mathrm{Lac}^{-} \mathrm{Cnt}^{-}$became $\mathrm{Lac}^{+} \mathrm{Cnt}^{+}$whereas strains BGM $132(\operatorname{codA}$ lac $Y)$ acquired the $\mathrm{Cod}^{+}$ and $\mathrm{Lac}^{+}$phenotypes after sexduction. Moreover we have detected in a copy of the Clarke and Carbon colony bank of E. coli (Clarke \& Carbon, 1976) a clone, pLC19-3, which is able to transmit both the $\mathrm{Cnt}^{+}$phenotype in a $\mathrm{Cnt}^{-}$strain (as BGM 160) and the $\mathrm{Cod}^{+}$phenotype in a $\mathrm{Cod}^{-}$strain (as BGM 182). In addition cells harbouring pLC19-3 showed a sixfold amplification of azide-induced cyanase over JA $200\left(\mathrm{cnt}^{+}\right)$or cells harbouring other clones from the colony bank. pLC19-3 from our copy gave the same qualitative and quantitative results as pLC19-3 obtained from Dr B. Bachmann (Coli Genetic Stock Center). 


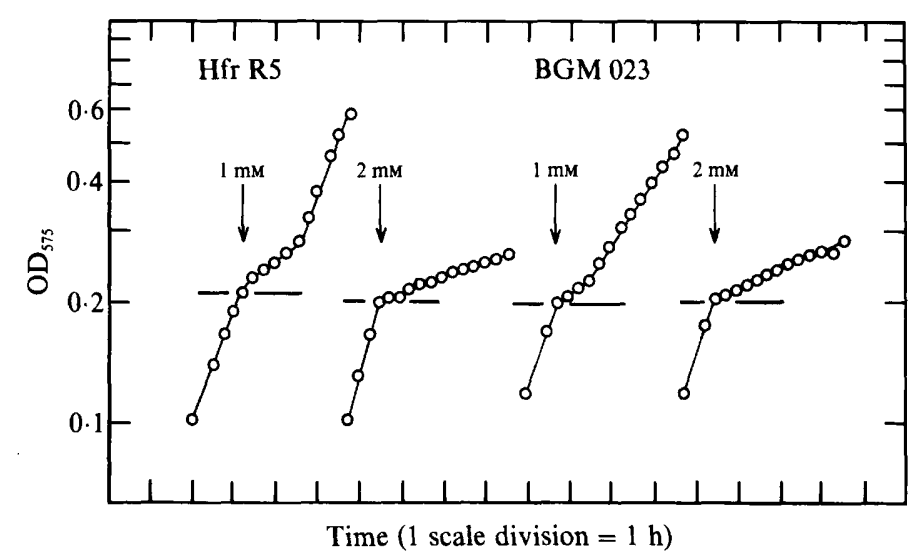

Fig. 2. Growth of strains Hfr R5 $\left(\mathrm{Cnt}^{+}\right)$and BGM $023\left(\mathrm{Cnt}^{-}\right)$in standard synthetic medium with the addition of cyanate ( $1 \mathrm{mM}$ or $2 \mathrm{mM}$ ) when the $\mathrm{OD}_{575}$ reached 0.2 (arrows). Generation times relative to this experiment are listed in Table 6.

Table 6. Doubling times of strains Hfr R5 and BGM 023 in the presence of various concentrations of cyanate

$\begin{array}{ccc}\begin{array}{c}\text { KNCO concn } \\ (\mathrm{mM})\end{array} & \overbrace{\text { Hfr R5 }}^{\text {Doubling time (min) }} & \text { BGM 023 } \\ 0 & 60 & 60 \\ 0.2 & 62 & 68 \\ 0.5 & 64 & 88 \\ 1.0 & 150^{*} & 130 \\ & 67^{*} & \\ 2.8 & >400 & >400 \\ 4.0 & >600 & >600\end{array}$

* Addition of 1 mM-cyanate to a culture of Hfr R5 was followed by two-phase growth (see text and Fig. 2).

\section{Growth inhibition induced by cyanate}

Effect of cyanate on wild-type and mutant strains. The physiological difference between wildtype strains $\left(\mathrm{Cnt}^{+}\right)$and $\mathrm{Cnt}^{-}$mutants lies in the sensitivity towards cyanate added to cultures in synthetic medium (Table 6, Fig. 2). Addition of moderate concentrations of cyanate $(<1 \mathrm{~mm})$ to cultures of wild-type strains (e.g. Hfr R5) did not produce perceptible inhibition and the added cyanate was progressively hydrolysed. On the other hand cultures of mutant strains (e.g. BGM 023) showed growth inhibition in the presence of cyanate concentrations as low as $0.2 \mathrm{mM}$ (Table 6); generation times observed for this strain were always higher than those for Hfr R5 in the presence of the same cyanate concentrations, and no cyanate hydrolysis occurred. Addition of 1 mM-KNCO to a culture of Hfr R5 induced a two-phase growth pattern (Fig. 2): a first phase with a generation time of $150 \mathrm{~min}$ was followed by almost normal growth with a generation time of $67 \mathrm{~min}$; added cyanate was completely hydrolysed at the end of the growth inhibition phase. Addition of $1 \mathrm{~mm}-\mathrm{KNCO}$ to a culture of mutant strain BGM 023 resulted in a transient growth inhibition after which a stable generation time of $130 \mathrm{~min}$ was observed. No cyanate hydrolysis occurred. Growth of both strains was equally inhibited by cyanate concentrations of $2 \mathrm{~mm}$ and higher: generation times were always longer than $400 \mathrm{~min}$ (Table 6, Fig. 2); no cyanate hydrolysis could be detected in either case and assay of cyanase in strain Hfr R5 showed that very low enzyme levels were obtained $\left[\sim 0.01\right.$ units $\left.(\mathrm{mg} \text { protein })^{-1}\right]$.

Influence of $\mathrm{pH}$ on inhibition by cyanate. This was studied with the $\mathrm{Cnt}^{-}$mutant strain BGM 023 (Table 7). Growth inhibition by $\mathrm{KNCO}$ was enhanced at higher $\mathrm{H}^{+}$concentrations. 
Table 7. Influence of $\mathrm{pH}$ on growth inhibition mediated by cyanate in synthetic medium

Standard synthetic medium was supplemented with $0 \cdot 1 \mathrm{M}$-MES and the $\mathrm{pH}$ of the resulting solution was adjusted to the indicated values with concentrated $\mathrm{H}_{3} \mathrm{PO}_{4}$ or $60 \%(\mathrm{w} / \mathrm{v}) \mathrm{KOH}$. The inoculum consisted of a mid-exponential-phase culture of BGM 023. The control doubling time for each $\mathrm{pH}$ value is the mean value of four determinations, with the standard deviation in parentheses. Potassium cyanate was added to test cultures when the $\mathrm{OD}_{575}$ reached $0 \cdot 2$.

\begin{tabular}{cccc} 
& \multicolumn{3}{c}{ Doubling time (min) } \\
pH & $\overbrace{\text { Control }}$ & $0.1 \mathrm{mm-KNCO}$ & $1 \mathrm{mM}-\mathrm{KNCO}$ \\
$7 \cdot 5$ & $61(6)$ & 68 & 80 \\
7.0 & $58(4)$ & 68 & 127 \\
6.5 & $58(6)$ & 75 & $>600$ \\
6.0 & $61(6)$ & 103 & $>600$ \\
5.5 & $57(5)$ & $>600$ & $>600$
\end{tabular}

Within experimental error, lowering the $\mathrm{pH}$ by 1 unit had the same effect on generation time as raising cyanate concentration by a factor of 10 . Since $\mathrm{pK}_{\mathrm{a}}$ of isocyanic acid is $3 \cdot 7$ (Boughton \& Keller, 1966), isocyanic acid concentration is proportional to $\left[\mathrm{H}^{+}\right]$in the $\mathrm{pH}$ range $7 \cdot 5-5 \cdot 5$. Thus, growth inhibition induced by cyanate is likely to be mediated by isocyanic acid.

We have observed that growth inhibition is essentially the consequence of a specific effect of cyanate on arginine biosynthesis (see the accompanying paper: Guilloton \& Karst, 1987). Since the metabolic target is likely to be intracellular, the influence of $\mathrm{pH}$ on cyanate-mediated growth inhibition might indicate that isocyanic acid (and not cyanate) is the molecular species that crosses the cell membrane.

\section{Physiological role of cyanase}

Cyanase and endogenous cyanate. Anderson (1980) postulated that cyanase could play a role in the detoxification of endogenous cyanate arising from the spontaneous dissociation of carbamoylphosphate. Carbamoylphosphate dissociates into cyanate and phosphate and its half-life is $38 \mathrm{~min}$ at $37^{\circ} \mathrm{C}$ (Allen \& Jones, 1964). Assuming that endogenous cyanate is toxic, inducible cyanase would represent an advantage for all bacteria synthesizing carbamoylphosphate.

We have screened our collection of $E$. coli strains and we found that only half of them are $\mathrm{Cnt}^{+}$. However, one should take this result with caution since laboratory strains of $E$. coli are propagated on media on which cyanase - according to the above hypothesis - would not be very useful; numerous transfers may lead to the loss of the $\mathrm{Cnt}^{+}$character. Moreover, some $\mathrm{Lac}^{-} \mathrm{Cnt}^{-}$ strains harboured deletions in the lac locus and these deletions might extend into the cnt locus.

We screened a number of strains purified from clinical swabs for the $\mathrm{Cnt}^{+}$character and found that only $60 \%$ of the $E$. coli strains $(82 / 137)$ tested possessed the $\mathrm{Cnt}^{+}$phenotype. Inducible cyanase was present in Serratia marcescens (16/16) and Pseudomonas aeruginosa $(61 / 66)$. Cyanase activity could not be demonstrated among a variety of other bacteria including Proteus species (0/53), Streptococcus faecalis (0/43) and Staphylococcus aureus (0/73). It was of particular interest that the five Salmonella typhimurium strains tested were all $\mathrm{Cnt}^{-}$. These observations suggest that if cyanase plays a role in destroying endogenous cyanate, this role may not be absolutely essential for bacterial survival.

Cyanase and exogenous cyanate. From the preceding results it may be seen that low concentrations of extracellular cyanate $(<0.2 \mathrm{mM})$ could inhibit growth of $\mathrm{Cnt}^{-}$cells provided that $\mathrm{H}^{+}$concentration is sufficiently high. Looking for such environmental conditions we found that solutions of urea $(0.1-0.5 \mathrm{M})$ could be considered as potential sources of cyanate. Calculations after Hagel et al. (1971) indicate that 0.3-0.5 $\mathrm{m}$ solutions of urea at $\mathrm{pH}$ 6-7 are able to generate concentrations of cyanate in the $0.1 \mathrm{~mm}$ range. Assay of cyanate in such urea solutions demonstrated that these concentrations were actually obtained after an incubation of 


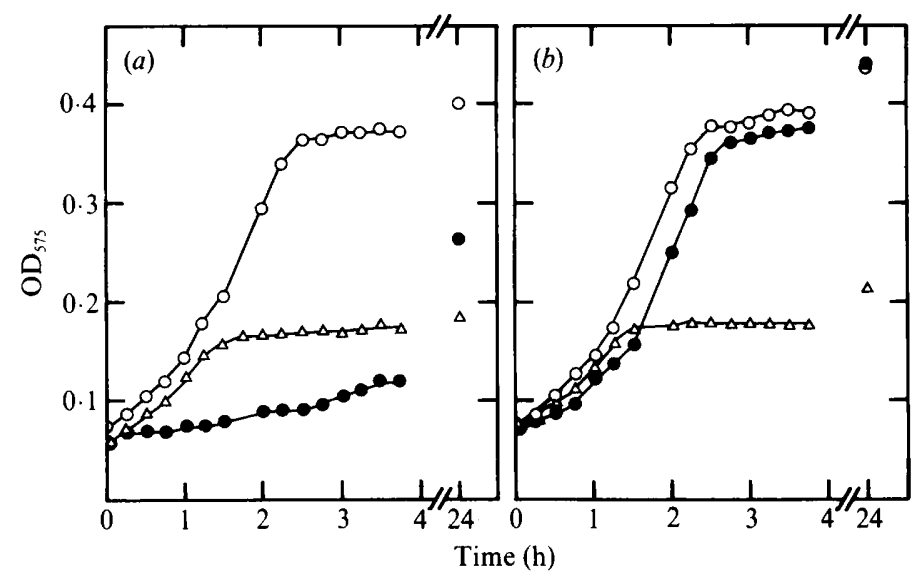

Fig. 3. Assimilation of ammonium from cyanate by $\mathrm{Cnt}^{+}$cells. E. coli strains BGM $023\left(\mathrm{Cnt}^{-}\right)(a)$ and C600 $\mathrm{F}^{\prime}$ lac $\left(\mathrm{Cnt}^{+}\right)(b)$ were cultivated in minimal medium from overnight cultures in the same medium. When the cultures reached mid-exponential phase they were diluted $1 / 20$ in minimal medium modified with respect to the nitrogen source $\left(\mathrm{O}, 1 \mathrm{mM}-\mathrm{NH}_{4}^{+} ; \mathrm{O}, 1 \mathrm{mM}-\mathrm{NCO}^{-} ; \triangle\right.$, no added nitrogen source); the $\mathrm{OD}_{575}$ of the diluted cultures was then monitored. Residual growth in the medium without nitrogen source could be accounted for by the presence of approximately $0.4 \mathrm{mM}-\mathrm{NH}_{4}^{+}$carried over in the inoculum. Growth of strain BGM 023 in the presence of cyanate could be accounted for by a slow assimilation of ammonium from the inoculum and spontaneous hydrolysis of cyanate (which has a halflife of $27 \mathrm{~h}$ at $37^{\circ} \mathrm{C}$ in the culture medium).

\section{Table 8. Cyanate formation in dilute solutions of urea}

Freshly made solutions of urea were sterilized by filtration and incubated at $37^{\circ} \mathrm{C}$. Cyanate concentration was estimated according to Guilloton \& Karst (1985).

$\begin{array}{clll}\text { Time } & \overbrace{\text { Initial urea concn: }}^{\text {Cyanate concn after }} \\ \text { incubation (mM) }\end{array}$

\section{Table 9. Influence of urea on growth of $\mathrm{Cnt}^{+}$and $\mathrm{Cnt}^{-}$strains}

Suspensions of $\mathrm{Cnt}^{+}$and $\mathrm{Cnt}^{-}$strains were deposited on a solid synthetic medium composed of $0 \cdot 1 \mathrm{M}$-MES, $5 \mathrm{mM}-\mathrm{KH}_{2} \mathrm{PO}_{4}, 8 \mathrm{mM}-\left(\mathrm{NH}_{4}\right)_{2} \mathrm{SO}_{4}, 1.7 \mathrm{~mm}$-trisodium citrate (pH adjusted to 6.5 with concentrated $\mathrm{KOH})$, plus glucose $(0.4 \%)$, thiamin hydrochloride $\left(1 \mu \mathrm{g} \mathrm{ml}^{-1}\right)$ and $2 \%$ agar. The salts solution and additives were mixed with molten sterile agar at $60^{\circ} \mathrm{C}$. Urea from a $10 \mathrm{M}$ filter-sterilized solution was added to the plates. Plates were incubated for $24 \mathrm{~h}$ at $37^{\circ} \mathrm{C}$ in order to ensure a preliminary dissociation of urea. Cell suspensions were deposited on the agar surface and plates were incubated for a further $48 \mathrm{~h}$. Growth was estimated semi-quantitatively from ++++ (excellent growth, as in the controls) to 0 (no growth).

Strain (genotype)
Hfr R5
BGM $022($ cnt2)
BGM $023(c n t 3)$
BGM $024(c n t 4)$
BGM 025 (cnt5)
Hfr H
BGM 035 (cnt 15)

Urea

$\begin{array}{cccc}\text { concn ... } & 0.3 \mathrm{M} & 0.4 \mathrm{M} & 0.5 \mathrm{M} \\ ++++ & ++++ & +++ \\ ++ & 0 & 0 \\ +++ & 0 & 0 \\ +++ & ++ & 0 \\ +++ & + & 0 \\ ++++ & ++++ & ++ \\ +++ & 0 & 0\end{array}$


$22 \mathrm{~h}$ at $37^{\circ} \mathrm{C}$ (Table 8). We tested the growth of wild-type $\left(\mathrm{Cnt}^{+}\right)$and mutant $\left(\mathrm{Cnt}^{-}\right)$strains on a solid synthetic medium containing various amounts of urea (Table 9). Urea at concentrations of 0.4-0.5 M inhibited growth of $\mathrm{Cnt}^{-}$strains while growth of $\mathrm{Cnt}^{+}$strains was little affected. Natural fluids, such as urine from ureotelic animals, can contain $0.3-0.4 \mathrm{M}$-urea. Therefore in these media cyanase-bearing strains could probably be at an advantage over other bacteria. We have also observed that $E$. coli strains with inducible cyanase $\left(\mathrm{Cnt}^{+}\right)$could grow in a synthetic medium with cyanate as the only nitrogen source whereas $\mathrm{Cnt}^{-}$mutants could not (Fig. 3). Therefore cyanate might constitute a convenient source of nitrogen for $\mathrm{Cnt}^{+}$bacteria.

Thus, cyanase could play a role in relation to exogenous cyanate; taxonomic studies of the $\mathrm{Cnt}^{+}$phenotype should help to identify the environmental conditions capable of maintaining cyanase in bacterial cells.

We wish to acknowledge Dr P. G. de Haan and Dr B. J. Bachmann for supplying E. coli strains, Dr M. Schwartz for supplying the P1 phage, Dr A. Piérard for a gift of a copy of the Clarke-Carbon colony bank and Dr Y. Rautlin de la Roy who supplied numerous purified bacterial strains from swabs. We thank Dr F. Nau for valuable collaboration in preparing the manuscript.

\section{REFERENCES}

Allen, C. M. \& Jones, M. E. (1964). Decomposition of carbamylphosphate in aqueous solutions. Biochemistry 3, 1238-1247.

ANDERSON, P. M. (1980). Purification and properties of the inducible enzyme cyanase. Biochemistry 19, 2882-2888.

BACHMANN, B. J. (1983). Linkage map of Escherichia coli K12, edition 7. Microbiological Reviews 47, 180230.

Boughton, J. H. \& Keller, R. N. (1966). Dissociation constants of hydropseudohalic acids. Journal of Inorganic Nuclear Chemistry 28, 2851-2859.

Chin, C. C. Q., Anderson, P. M. \& Wold, F. (1983). The aminoacid sequence of Escherichia coli cyanase. Journal of Biological Chemistry 258, 276-282.

Clarke, L. \& Carbon, J. (1976). A colony bank containing synthetic ColEl hybrid plasmids representative of the entire $E$. coli chromosome. Cell $9,91-$ 99.

Guilloton, M. \& Hargreaves, A. B. (1972). Hydrolyse du cyanate par une bactérie du genre Flavobacterium. Comptes rendus hebdomadaires de l'Académie des Sciences, Série D 275, 1827-1830.

GuIlloton, M. \& KarST, F. (1985). A spectrophotometric determination of cyanate using reaction with 2-aminobenzoic acid. Analytical Biochemistry 149, 291-295.

Guilloton, M. \& Karst, F. (1987). Cyanate specifically inhibits arginine biosynthesis in Escherichia coli K12: a case of by-product inhibition? Journal of General Microbiology 133, 655-665.

de HaAn, P. G., Felix, H. S. \& Peters, S. (1972).
Mapping of the gene for cytosine desaminase on the E. coli chromosome. Antonie van Leeuwenhoek 38, 257-263.

Hagel, P., Gerding, J. J. T., Fieggen, W. \& BloEmendal, H. (1971). Cyanate formation in solutions of urea. I. Calculation of cyanate concentration at different temperatures and $\mathrm{pH}$. Biochimica et biophysica acta 243, 366-373.

HANE, W. P. \& Wood. T. H. (1969). Escherichia coli K12 mutants resistant to nalidixic acid: genetic mapping and dominance studies. Journal of Bacteriology 99, 238-241.

Lubochinsky, B. \& Zalta, J. P. (1955). Microdosage colorimétrique de l'azote ammoniacal. Bulletin de la Société de chimie biologique 36, 1363-1366.

MARIER, J. R. \& Rose, D. (1964). Determination of cyanate, and a study of its accumulation in aqueous solutions of urea. Analytical Biochemistry 7, 304-314.

MILLER, J. H. (1972). Experiments in Molecular Genetics. Cold Spring Harbor, NY: Cold Spring Harbor Laboratory.

TAussig, A. (1960). The synthesis of the induced enzyme cyanase in Escherichia coli. Biochimica et biophysica acta 44, 510-519.

WAGNER, E. L. (1965). Calculated binding in the pseudohalide anions and their hydracids. Journal of Chemical Physics 43, 2728-2735.

Wilson, G. G., Young, K. K. Y., Edlin, G. J. \& Konigsberg, W. (1979). High frequency generalized transduction by bacteriophage T4. Nature, London 280, 80-81. 